FOLIA HISTORICA CRACOVIENSIA, 21: 2015, s. 297-303

DOI: http://dx.doi.org/10.15633/fhc.1740

Stanisław Koc

\title{
Odpowiedź na recenzję M. Danielewskiego książki Zjednoczenie Królestwa Polskiego - wpływ zagrożenia zewnętrznego 1210-1410
}

Marcin Danielewski nie pierwszy raz recenzuje książkę mojego autorstwa. Odnosząc się do jednej z wcześniejszych moich publikacji Inowrocław, Krzyżacy a zjednoczenie Królestwa Polskiego, przypisał mi twierdzenia, których tam nie zamieściłem. Także obecnie recenzja M. Danielewskiego opiera się na swoistego rodzaju nieporozumieniu. Autor chyba nie do końca zrozumiał charakter mojej pracy, mimo iż dość przejrzyście starałem się we wstępie wyjaśnić cele, jakie sobie postawiłem. Przytoczyłem wówczas zdanie Antoniego Gąsiorowskiego, który zwrócił uwagę na fakt, iż mimo upływu ponad siedemdziesięciu lat, nadal najbardziej szczegółowym kompendium historii politycznej średniowiecznej Polski jest podręcznik Stanisława Zachorowskiego, Romana Grodeckiego i Jana Dąbrowskiego. W jego ocenie, jest to spowodowane odwrotem polskiej historiografii od historii politycznej, najpierw na rzecz historii gospodarczej, potem społecznej ${ }^{1}$. Nie oznacza to oczywiście, że nie ma późniejszych prac historyków, w których zajmują się oni wybranymi zagadnieniami politycznymi. Należy jednak zauważyć, iż prace przekrojowe z XIII i XIV wieku najczęściej bazują na tym właśnie kompendium $\mathrm{z}$ lat 20. xx wieku, aktualizując treść w miejscach, gdzie dokonano nowych ustaleń. Dotyczy to także prac zbiorowych, w których poszczególne rozdziały powierzono do napisania historykom specjalizującym się w poruszanej przez nich tematyce. Jest to częścią znacznie zresztą szerszego zjawiska powoływania się, najczęściej we wstępie, na ustalenia wcześniejszych historyków, które uważa się za niewątpliwe i w związku z tym taka publikacja nie podlega już dalszej ocenie. Nowe ustalenia są przybudówkami starszych stanowiących jak gdyby rdzeń. A przecież historia nie jest dziedziną nauki, którą

${ }^{1}$ A. Gąsiorowski, Kazimierz Wielki w Trnawie latem 1362 roku. Nad zagadnieniami historii politycznej średniowiecznej Polski, [w:] „Przegląd Historyczny” 89 (1998) z. 3, s. 473-474. 
można empirycznie poznać. Większość stwierdzeń, oprócz analiz dokumentów i źródeł materialnych, to również hipotezy i przypuszczenia. Nasuwa się więc postulat nowego spojrzenia na całość dziejów politycznych Polski w średniowieczu, podobnie jak dokonało tego trzech wspomnianych historyków międzywojnia. Takie właśnie zadanie sobie postawiłem - uporządkowania materiałów zebranych przez różnych historyków, w tym także, a może przede wszystkim autorów publikacji uważanych za swego rodzaju biblię. Stąd taki, a nie inny wybór bibliografii, który obejmuje wyłącznie prace, gdzie porusza się problematykę istotną dla danej kwestii. Moim zadaniem nie było zebranie wszystkich publikacji, które nawiązują tytułem do danej tematyki, a w rzeczywistości nowe w nich treści dotyczą zagadnień obocznych.

Interesował mnie przy tym, jak to wskazałem na wstępie recenzowanej książki, przede wszystkim tok rozumowania autorów. Badanie źródeł opiera się bowiem zarówno na interpretacji przekazów wynikających $\mathrm{z}$ ich treści i formy, jak i w znacznej mierze dokonuje się przy tej okazji analizy przyczyn i przebiegu wydarzeń, co nierzadko wpływa na interpretację samego źródła. O ile treść dokumentów jest znana od dawna i cytowana przez wielu autorów, o tyle interpretacja wydarzeń najczęściej jest w sferze hipotez, ale one właśnie pozwalają na przekształcenie suchych faktów w ciąg wydarzeń przyczynowo-skutkowych, słowem zrozumienie: co, kto i dlaczego. Obecnie historycy unikają rozważań, które zajmowałyby się samą tylko analizą przebiegu wydarzeń, ale czasami uznają to za konieczność. Przykładem może być praca S. Szczura, zajmująca się problematyką zrzeczenia się Śląska przez Kazimierza Wielkiego w roku 1339, która zwróciła moją uwagę w kontekście zarzutów M. Danielewskiego tłumaczeniem autora, dlaczego zdecydował się na taki krok ${ }^{2}$. Nikt jednak S. Szczura za to nie zganił tak, jak w przypadku mojej książki. Niektórzy autorzy przy tego typu pracy rezygnują nawet $\mathrm{z}$ zamieszczania przypisów. B. Nowacki opisując czasy Przemysła I, uznał, iż nie mają one znaczenia dla stworzenia spójnego obrazu dziejów Wielkopolski w czasie rządów tego księcia ${ }^{3}$. Tymi samymi przesłankami mogli kierować się S. Zachorowski, R. Grodecki i J. Dąbrowski, którzy także zrezygnowali z przypisów ${ }^{4}$. Nie oznacza to, że prace te nie są cytowane. Przeciwnie, mają duże znaczenie dla badaczy dziejów średniowiecznej Polski. Niemniej

${ }^{2}$ S. Szczur, Okoliczności zrzeczenia się Śląska przez Kazimierza Wielkiego w roku 1339, [w:] „Studia Historyczne. Kwartalnik” 30 (1987) z. 4 (119), s. 520.

${ }^{3}$ B. Nowacki, Przemysł I syn Władysława Odonica, książę wielkopolski 1220/1221-1257, Poznań 2003, s. 5n.

${ }^{4}$ S. Zachorowski, R. Grodecki, J. Dąbrowski, Dzieje Polski średniowiecznej, Warszawa 1926. 
obecnie podstawowe wydarzenia $\mathrm{z}$ historii Polski XıII i XIV wieku tłumaczy się zjawiskami natury społecznej. Przykładem może być książka S. Gawlasa O kształt zjednoczonego Królestwa $a^{5}$. Pokazuje to, iż dotychczasowe badania historyków nad wybranymi zagadnieniami politycznymi muszą być uporządkowane $\mathrm{w}$ jeden spójny obraz. Taki właśnie racjonalizatorski charakter ma moja książka.

Efekt przekroczył moje najśmielsze oczekiwania. Na bardzo wiele z pozoru niewyjaśnionych spraw okazało się, że można było znaleźć odpowiedź. Po raz pierwszy w polskiej historiografii przedstawiłem hipotezę, iż Konrad Mazowiecki i inni Piastowie sprowadzili Zakon Krzyżacki, aby zlikwidować misję cysterską w Prusach, na której czele stał biskup Chrystian. Po pokonaniu Chrystiana możliwy był dopiero atak na Świętopełka, którego za poparcie cystersów papież wspierał w jego dążeniach uniezależnienia się od Polski. Wyjaśniłem m.in. także, iż książęta mazowiecko-kujawscy i małopolski przy poparciu książąt włodzimiersko-halickich, liczyli na przekazanie im misji w Prusach i uchylenie przez papieża zakazu wkraczania na ziemie pruskie. Papież nie mógł bowiem prawosławnym władcom zakazać wkraczania na teren Prus, zwłaszcza że zależało mu na uznaniu przez nich jego zwierzchnictwa. Pokazałem także, iż konflikt papiestwa i cesarstwa o supremację w świecie chrześcijańskim doprowadził do rozkładu dawnych trybutarnych praw Rzeszy do Pomorza i niepowodzenia lansowanej przez cesarza koncepcji zwierzchności nad ziemiami Bałtów. Papież najpierw uznał niezależność panowania Świętopełka na Pomorzu Gdańskim, później zaś nadał Prusy Zakonowi. Odpowiedzią cesarza było nadanie Pomorza Zachodniego margrabiom brandenburskim, później zaś przymuszenie Zakonu do przyjęcia Złotej Bulli, która jednak nie naruszała wcześniejszego przywileju papieża. Konflikt ten będzie miał niebagatelny wpływ na zaostrzenie stosunków polsko-brandenburskich mimo początkowo sojuszu Przemysła z margrabiami przeciwko książętom zachodniopomorskim. Wojna z Marchią o ziemie na pograniczu pomorsko-wielkopolskim skłoniła margrabiów do poparcia króla czeskiego przeciwko Łokietkowi, który w ten sposób utracił władzę w Wielkopolsce, Pomorzu i na Kujawach. Zagrożenie sojuszem czesko-brandenburskim po raz pierwszy zrozumiał Henryk IV Probus, którego ambicje zjednoczeniowe początkowo popierali zarówno król niemiecki, jak i czeski spodziewając się wojny z Węgrami w przymierzu z Leszkiem Czarnym i opozycją w Czechach. Testament księcia wrocławskiego, uderzając $\mathrm{w}$ interesy brandenburskie osłabiał pozycje czeskie w Polsce. Oddając śląskie posiadłości Henrykowi głogowskiemu, a małopolskie

${ }^{5}$ S. Gawlas, O kształt zjednoczonego Królestwa. Niemieckie władztwo terytorialne a geneza społeczno-ustrojowej odrębności Polski, Warszawa 2000. 
Przemysłowi wielkopolskiemu, Probus zarazem powołał koalicję, która mogła się wspierać $\mathrm{w}$ walce $\mathrm{z}$ Wacławem. Ostatecznie to interwencja cesarza rozbiła sojusz królów czeskich z Brandenburgią, choć Przemyślidzi próbowali jeszcze go uratować, oddając margrabiom jednostronnym aktem Pomorze Gdańskie. Porażka królów czeskich utorowała drogę do powrotu Łokietkowi, którego odtąd głównym celem było zapobiegnięcie odnowieniu sojuszu Czech i Marchii. Stąd podjęcie ryzyka i zaproszenie Krzyżaków do opanowanego przez Marchię Pomorza Gdańskiego. Jednocześnie utrzymywanie polskich załóg w grodach w Gdańsku, Tczewie i Świeciu miało umożliwić odzyskanie władzy nad Pomorzem po zakończeniu wojny między margrabiami i Krzyżakami oraz wycofaniu się z walk jednej z tych sił. Zakon nie dał się zwieść i do walki przystąpił dopiero po oddaniu części grodu gdańskiego. Wyzyskując rycerstwo pomorskie wierne królowi polskiemu, Krzyżacy wypierali margrabiów. W chwili wycofania się głównych sił brandenburskich z Gdańska doprowadzili do uszczuplenia sił polskich na Pomorzu i opanowali cały gród w Gdańsku. Po uzyskaniu przewagi i upewnieniu się, iż kierownictwo polskie nie zorientowało się w sytuacji, zajęli błyskawicznie w tym samym czasie miasto Gdańsk i gród w Tczewie. Zwycięstwo Zakonu osłabiło Polskę przez utratę Pomorza Gdańskiego, z drugiej strony zagwarantowało pokój od strony Czech, gdyż Zakon zaspokoiwszy swoje ambicje terytorialne liczył na stworzenie trwałego sojuszu z Polską przeciwko Marchii. Dlatego nie zajął, chociaż miał taką możliwość, przygranicznego z Pomorzem księstwa inowrocławskiego. Zainteresowania Łokietka w takiej sytuacji mogły skierować się w kierunku Wielkopolski, a co za tym idzie Śląska i Marchii. Zakon próbował jednak uzyskać formalne uznanie swoich praw do Pomorza Gdańskiego i w chwili podjęcia przez księcia kujawskiego starań o koronę, zawarł dyplomatyczny sojusz z królem czeskim. Papież, oddając koronę Łokietkowi, pozostawił nierozstrzygnięty jego spór z Luksemburgami co do tronu w Polsce, jednocześnie wsparł bardzo jednoznacznie roszczenia polskie do Pomorza. Przełożyło się to na korzystny wyrok przed trybunałem papieskim w Inowrocławiu. Zakon obawiając się wzmocnienia władzy królewskiej w Polsce, co mogło zaowocować egzekucją zasądzonego zwrotu jej posiadania Pomorza, wolał na tronie słabego Łokietka niż któregoś z wielkich monarchów europejskich. Łokietek zyskał w ten sposób możliwość ingerencji na Śląsku, Pomorzu Zachodnim i Marchii, co chciał też wykorzystać papież w swojej polityce względem Niemiec. Działania Łokietka nie zawsze były zgodne z polityką kurii, generalnie dążył do zajęcia jedynie Nowej Marchii, która oddzielała Pomorze od Śląska i skupiał się na sprawach polskich. Konieczność liczenia się z papieżem, ze względu na Zakon, osłabiała możliwość działania Łokietka i zmusiło go to do zawarcia sojuszu z książętami głogowskimi 
o charakterze antyniemieckim po ich oddaniu się pod opiekę papieską. Cesarz zareagował poparciem dla Henryka vi wrocławskiego, później zaś zgodził się na opanowywanie Śląska przez króla czeskiego. Zakon jednak nie chciał nadal współpracować przeciwko Polsce z królami Czech czy Niemiec. Dopiero zgodził się na zawarcie sojuszu z Luksemburgami, który to sojusz miał jednocześnie wydźwięk antyniemiecki. Świadczy o tym poparcie Zakonu przeciwko Marchii książąt pomorskich i układy lenne króla czeskiego z książętami śląskimi gwarantujące im ochronę przed cesarzem. Piastowie śląscy byli tutaj przymuszeni, gdyż nie mogąc liczyć na Łokietka znaleźli się w niebezpieczeństwie ze strony cesarza, przeciwko którego planom co do Marchii wystąpili wcześniej z królem polskim. Ponadto Zakon uzyskał od Czech nadania połowy Mazowsza i ponownie Pomorza Gdańskiego, co było konieczne ze względu na brak pewności praw do niego, do czego przyczynił się papież, pozwalając na proces przeciwko Zakonowi i wydanie korzystnego dla Polski wyroku. Wittelsbachowie zagrozili jednak interesom czeskim $w$ innych regionach, a król czeski stał się wkrótce sojusznikiem króla polskiego $\mathrm{w}$ walce $\mathrm{z}$ nimi.

W tym okresie wykrystalizowała się wyraźnie antyniemiecka polityka Zakonu (nie mówię o propagandzie, która zawsze oficjalnie była proniemiecka, co przynosiło Zakonowi określone profity). To właśnie ona stanowiła gwarancję niezależności Polski, co dowiodłem powyżej. Apogeum stosunków polsko-krzyżackich stanowił schyłek panowania Kazimierza Wielkiego, który planował stworzyć buforowe terytorium między Polską i Zakonem przez oddanie całych Kujaw łącznie z ziemią sieradzką i łęczycką książętom pomorskim. Sam zaś zbrojnie chciał zająć z pomocą Głogowczyków Śląsk i uczynić jednego z nich, Konrada II oleśnickiego, swoim następcą. Pomysł ten żywy był jeszcze za czasów Jagiełły. Dopiero wielka wojna z Zakonem, do której Polskę namawiali królowie czescy i niemieccy już od połowy x IV wieku, udaremniła plany zjednoczeniowe Śląska i Pomorza Zachodniego z Polską w oparciu o współpracę z Państwem Zakonu. W ten sposób dokonałem całkowitego przewartościowania ocen wojen z Zakonem w XV i XVI wieku, które choć zakończyły się jego pokonaniem, były właściwie klęską Polski. Jednocześnie proces polsko-krzyżacki w Inowrocławiu i Brześciu Kujawskim jawi się jako jeden z największych sukcesów dyplomatycznych w dziejach Polski. Bardziej niż jakakolwiek wojna przyczynił się do zneutralizowania jej wrogów i ukształtowania, jak to nazywam, polskiego systemu politycznego opartego z jednej strony na Polsce, z drugiej na Państwie Zakonu. Podobna polityka tych dwóch podmiotów w odniesieniu do Śląska i Pomorza Zachodniego podtrzymywała dużą niezależność tych ziem. Działania sąsiednich władców w Polsce na skutek polityki Zakonu obliczone były na zawarcie sojuszu 
z małymi książętami na Śląsku, nie miały zaś charakteru bezpośredniego. Dotyczy to nawet potężnych władców niemieckich, którzy potrafili pokonać militarnie sojusz Czech, Polski i książąt pomorskich. Próba wykorzystania przez Wittelsbachów książąt głogowskich, ściągnęła na nich niszczycielski najazd Kazimierza Wielkiego (natomiast według obiegowego poglądu Polsce chodziło tylko o zajęcie Wschowy).

Wnioski wypływające z 200 lat historii w okresie od roku 1210 do roku 1410 mają ogromne znaczenie dla oceny całej polityki zachodniej I Rzeczypospolitej. Zagadnienia te rzadko pojawiają się w literaturze, właściwie jedynie w kontekście strat terytorialnych. Stąd w zakończeniu książki uznałem za konieczne nawiązanie do okresu po 1410 roku. Nadal bowiem wysuwano kolejne projekty wznowienia sojuszu z Zakonem, opierające się o Gryfitów i cesarstwo lub na zasadzie jego lennej zależności od Polski. Ostatecznie nastąpiło oparcie polskiej polityki względem ziem zachodnich na Prusach. Zdefiniowanie polskiej polityki zachodniej pozwala więc na poznanie genezy Prus, jak też określenie historycznych ziem polskich, które obejmowały niewątpliwie Śląsk i Pomorze Zachodnie. Uzasadnia to stosowanie pojęcia ziem odzyskanych, które tak łatwo się dzisiaj odrzuca bez wnikliwej oceny ich sytuacji politycznej, tylko na podstawie stosunków narodowościowych przed katastrofą, jaką była II wojna światowa. Tymczasem koła rządzące w Prusach oficjalnie powoływały się na tradycje piastowskie na Śląsku i gryfickie na Pomorzu, podkreślając nierozerwalny związek Prus z Polską. Za przyzwoleniem Polski uzyskały te ziemie, następnie przystąpiły do rozbiorów, obejmując swymi granicami niemal wszystkie ziemie piastowskie za wyjątkiem Małopolski. To polityczne zwycięstwo w istocie polegało na zjednoczeniu ziem rdzennie polskich. Prusy, gdyby trwały w tych granicach dłuższy czas, miały szansę przejąć nawet tradycje polityczne dawnej Rzeczypospolitej. Wielowiekowy związek Polski i Prus rodził bowiem projekty odbudowy Polski w oparciu o ideę wspólnej państwowości z Prusami. Napoleon przyczynę swej klęski upatrywał m.in. w tym, że ziemie oderwane od Prus i oddane Polakom nie połączył pod berłem króla pruskiego. Realizując ten stary plan, jeszcze Jagiellonów, zyskałby groźnego sojusznika w walce z Rosją. Oddzielenie Królestwa Polskiego od Prus otworzyło ranę i pociągnęło za sobą liczne powstania, powodując ukształtowanie się zupełnie innej mentalności Polaków w zaborze rosyjskim, którzy w walce upatrywali szansę na odzyskanie niepodległości. Natomiast w zaborze pruskim, na Śląsku i Pomorzu Polacy nadal pozostali związani z Prusami. Być może był to jeden z głównych czynników germanizacyjnych.

Natomiast odnosząc się do poruszonej przez M. Danielewskiego kwestii fary na rynku w Inowrocławiu, odsyłam Czytelnika do mojej najnowszej książki 
Zabytki Inowrocławia - archeologiczno-architektoniczne zagadnienia po badaniach w roku 2010. Dodam, że nie jest to odosobniona sytuacja, kiedy mimo odkrycia reliktów kościoła i wskazówek pozwalających na ich identyfikację, doniesienia na ten temat latami oczekują na oficjalne potwierdzenie. Przykładem może być odkrycie reliktów romańskiej świątyni z dawnego grodu Czerwień (dziś Czermno), głównego ośrodka Grodów Czerwieńskich ${ }^{6}$. W Inowrocławiu taki sam problem jest $\mathrm{z}$ nawą kościoła franciszkanów, gdzie poprzestano na ustaleniu przebiegu jednej ze ścian i stworzeniu na tej podstawie całkowicie dowolnej makiety tej świątyni (o czym także w Zabytkach Inowrocławia...).

${ }^{6}$ M. Bielesz, Nazywam się Czerwień, „Gazeta Wyborcza” z 2 listopada 2010, nr 256.7074 (http:// wyborcza.pl/1,75476,8601329,Nazywam_sie_Czerwien.html). 